\title{
THE USE OF 3-DIMENSIONAL GRAPHIC DISPLAY METHOD FOR PRESENTING THE CHANGES IN WEATHER
}

\author{
L. GIMESI \\ University of Pécs, Faculty of Natural Sciences, Department of Informatics \\ 6 Ifjúság Road, Pécs H-7624 \\ (phone: +36-72-503-600; fax: +36-72-503-697) \\ e-mail:gimesi@ttk.pte.hu \\ $\left(17^{\text {th }}\right.$ January 2008 ; accepted $6^{\text {th }}$ February 2008)
}

\begin{abstract}
Several methods have been worked out by now to present the changes of weather and its elements. In this article we present a graphic method where the changes of the different elements of the weather can be analised with the help of 3D figures. The tendency of changes can be seen well from the expressive, spatial plots.During the execution of the task several models to prepare the spatial surfaces (moving average, kriging, spline, inverse distance weighting, and artificial neural network) have been used and compared. Here the daily amount of precipitation measured at the meteorological station of Szeged has been analised. For the sake of better demonstration the measurement data with the help of a digital surface model has been illustrated. In connection with this a graphic display method, with which the presentation of the tendencies in the changes of precipitation are more expressive then the ones quoted in the literature has been presented earlier. Our method is presented with displaying time series, consisting of the daily amount of precipitation of 100 years, which has meant a separate challenge, as the precipitation data show significant deviation. We have already used the presented method for the demonstration of temperature and evaporation data as well.
\end{abstract}

Keywords: digital surface model, precipitation change, artificial neural network, moving average

\section{Introduction}

Climate change has become a central question in all fields of life, mainly because of its agricultural and ecological effect. In particular the examination of weather changes is important. Temperature and precipitation are important meteorological elements from the respect of the life conditions of plants. These factors mean not only the conditions necessary for the life and spread of the plants, but also the most important meteorological effects in the life of plants [14].

Several methods have been worked out by now for the presentation (visualization) of variation in precipitation, an important parameter of climate change.

Picture displays are closer to human thinking than large tables containing numerical data, which give exact information, but are harder to manage and are not suitable for the presentation of correlations. It can be helpful if we display our data graphically in the analysis of the calculation results, in a more interpretable form. Methods can be found for the display of precipitation change, where two-dimensional graphs are used $[2,6,7]$.

For the display of monthly (seasonal) and yearly precipitation change with graphs examples can be found in few publications. In these papers, the authors represent the seasonal and the yearly changes separately. There is a good example on the two potentials in rainfall event studies for Keszthely. The traditional prospect was provided by $[11,12]$, where graphs were applied to characterise yearly and seasonal variations in the precipitation of the small town. Another method, the neural network was also applied for the same data set together with evaporation of Lake Balaton [25]. The difference between these two applied methods is the chance in visualisation, where the neural network as a process is beneficial "only" for the eyes of the stakeholders. 
Analyzing the formerly used methods $[1,3,7]$ it can be said that they do not give enough information about the change. It is because no conclusion can be drawn about the seasonal (daily, monthly) changes on a yearly bases. In a case when we want to get information about the yearly tendencies from the seasonal changes we have to use unmanageable amount of graphs (in our case 100 pieces) at the same time.

Our aim was to combine the two display methods (seasonal and yearly) and depict them on a single graph. To see these two kinds of trends in a single picture, we used the technology employed in GIS (Geographical Informations Systems), so we displayed the precipitation data in 3D, with the help of a digital surface model. A similar model has been reviewed in [16], where the changes in vegetation are presented.

It cannot be ignored during the examination, that the results and the conclusion drawn from them are highly influenced by the used calculation algorithms. Different conclusions can be drawn depending on the chosen method from the same starting data [21]. In order to choose the best procedure from the smoothing and interpolation methods necessary for the preparation of digital surfaces, we have also compared the different methods. Besides such models, used in GIS (kriging, spline and inverse distance weighting) [22], we also used ANN (Artificial Neural Network) which is used more and more often to model climate changes. An ANN model has been reviewed for seasonal, global, and climate change in [2], [24], and [1, 2, 8] respectively.

Besides those, mentioned above, we also used another method that is widely spread for the representation of climate data; the moving average model.

\section{Material and method}

The material of the examination was provided by the data of daily precipitation, measured in Hungary for 100 years (from $1^{\text {st }}$ January 1901 to $31^{\text {st }}$ December 2000), based on the information collected by meteorological stations of ten cities of the Carpathian Basin (Vien, Budapest, Debrecen, Graz, Kalocsa, Keszthely, Mosonmagyaróvár, Sarajevo, Szeged, and Zagreb). The precipitation data have been provided by the Hungarian Meteorological Service, with an accuracy of $0.1 \mathrm{~mm}$. Because of size restrictions it is not possible to represent all the local data lines of every meteorological station, therefore the data line of Szeged has been chosen, as this area represents the typical warm continental weather in our country [3]. Based on meteorological literature the minimum of precipitation was set to $0.1 \mathrm{~mm}$, the lowest category for rainfall amount measurements.

A Visual Basic software have been used for the grouping and evaluation of data, and also for the calculation of the moving average program written in Visual Basic language. AutoCAD (Autodesk Inc.) and ArcView (GIS by ESRI) programs have been used for the presentation of the numerical data got by the neural network and the software. The methods of ArcView have been used for the calculation and presentation of kriging spline and inverse distance weighting.

Several models have been compared for the display of the calculation and results (the preparation of drawings). The Artificial Neural Network (ANN) [4], spatial moving average, kiging, spline and the method of inverse distance weighting [22].

\section{Digital surface model}

The digital surface model, an ordinary 3D geometric space (scalar or vector space); its coordinates: 


$$
r=x i+y j+z k \text {. }
$$

The scalar space can be described by a three variable function:

$$
\varphi=\varphi(x, y, z) \text {. }
$$

If we suppose that the space functions have one value, are continuous, and they are differentiable functions of the space coordinates; and as well the coordinate $z$ depends only on $x$ and $y$, then it can be written also as $z=f(x, y)$ [13].

In this task, in the 3D coordinate system, $x$ means the days in the year $\left(1^{\text {st }}\right.$ January $31^{\text {st }}$ December), $y$ means the years (1901-2000), while $z$ means the amount of precipitation measured on the given day. This is represented by Fig. 1, based on the amount of precipitation, from which it can be seen that the scalar space is not continuous and also that no conclusions can be drawn from the figure in its present form.

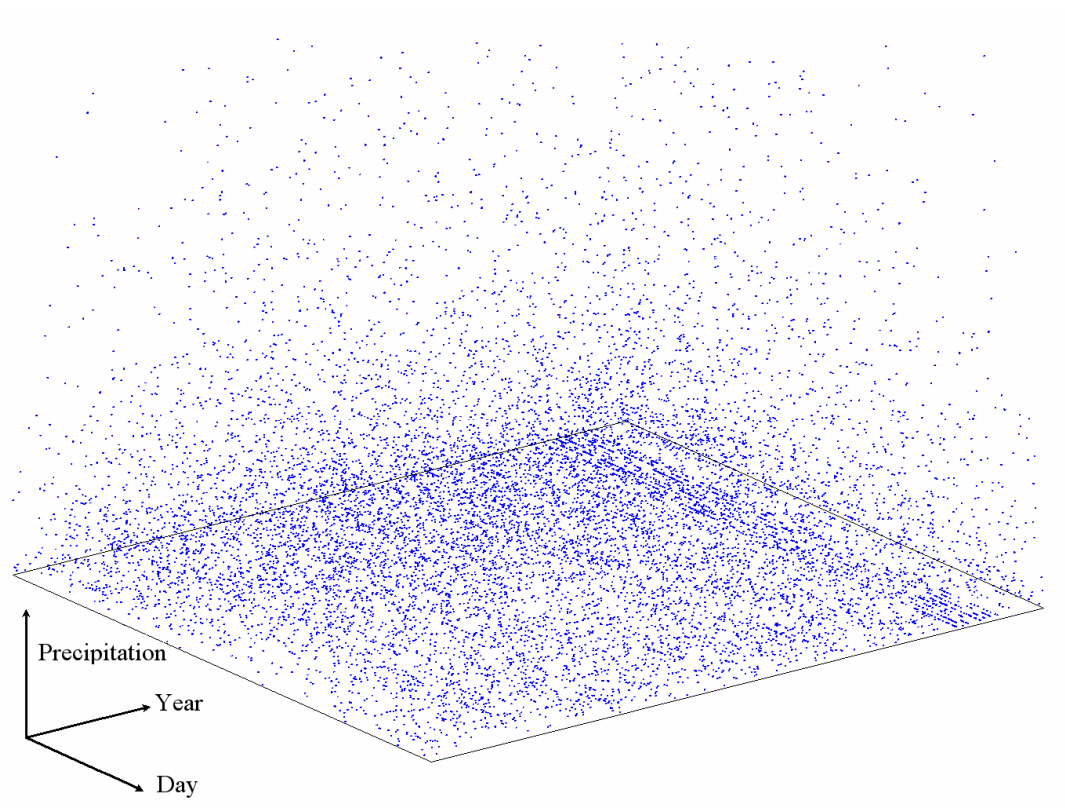

Figure 1. The 3D figure of the precipitation measured in Szeged (from 1901 to 2000)

For the geometric representation of the scalar space several methods are known: the level surfaces (where: $\varphi=\varphi(x, y, z)=k o n s t$ ), the subtle and the space curve's perspective and axonometric representation. The latter two methods provide spectacular graphs, but these are only suitable mainly for qualitative evaluation. For the solution of the task the subtle display has been chosen, supported by the ArcView program, too.

For the display of digital surfaces several methods are mentioned in the literature Inverse Distance Weighting, Kriging, Spline, ANN literature [1, 15, 19, 20, 23]. These cannot be used directly for our - special - case, because the spread of precipitation changes randomly (stochastically), so we cannot get a surface smooth enough for the interpolation with the methods mentioned above. If the number of data is decreased, these methods can be appropriate for the drawing. To reduce the number of the data, monthly, 5 and 10 year averages were used.

An appropriately finely divided, imaginary net is laid for the drawing of the scalar space, on the points of space, the cells of which are considered homogeneous. (The 
place of the cell gives the $x$ and $y$ coordinates of the drawing, the value of the cell gives the $z$ coordinate). As for the preparation of the drawing the knowledge of all the cell values are needed, the unknown cell data can be determined by interpolation.

\section{The used methods of interpolation:}

\section{Artificial Neural Network method, ANN}

The literature deals with ANN modeling and its use in detail $[1,4,8,18]$, therefore we point out only the essence.

ANN is a model which is able to learn and based on biological analogy. It is possible to recognize hidden connections between data and to solve tasks based on estimation with the help of it.

The processing unit (the basic unit) of ANN is the neuron, which is shown in Fig. $2 a$. The response (denoted by $i$ ) arriving from the outside world or other nerve-cells gets to the nerve-cell via the synapses. A weight $(w)$ is used in the model to reflect the strength of the synapses' response. The incoming responses are summed up on the surface of the nerve-cell as follows:

$$
x=\sum_{j=1}^{n} i_{j} w_{j} .
$$

If the resultant stimulus $(x)$ reaches a threshold, then a response $(y)$ is formed, which is passed on to the next nerve-cell. Let the "transfer function" of the nerve-cell be $f$, this way the formed response is:

$$
y=f\left(\sum_{j=1}^{n} i_{j} w_{j}\right) .
$$

The simplified structure of the ANN model which is formed by nerve-cells. It is used to solve this task as presented by Fig. $2 b$.

(a)

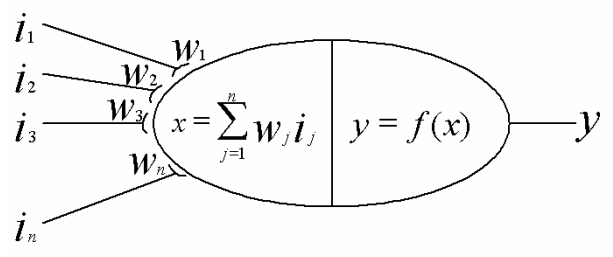

(b) Input layer

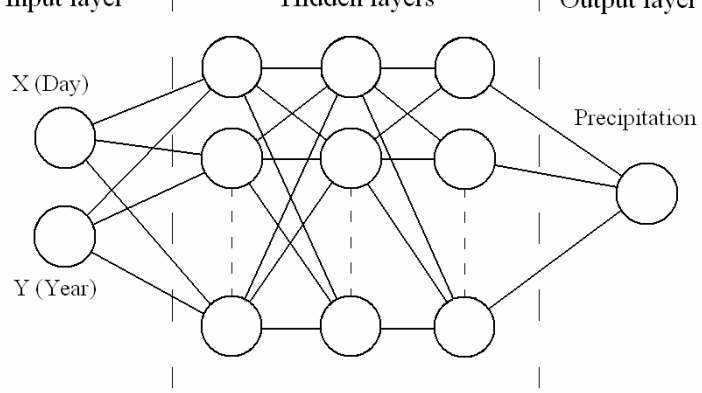

Figure 2. The model of the nerve-cell and the neural network

The response receptive (sensory) cells form the input layer. Here are as many neurons as the kinds of input data (variables) belonging to a task. In this case these are the coordinates of $x$ (days) and $y$ (years).

The next (hidden) layers represent the nervous system, where the neurons of a layer can be connected to each neuron of the previous layer. Several theories have been arisen to determine the number of the necessary neurons. Experience shows that it cannot be determined exactly, therefore the up-to-date simulation (modeling) softwares can change the number of sub-layers and neurons according to need. In our recent task three sub-layers and for each layer 22 neurons were used. 
The answer given to the stimuli - just like in the nervous system - appears on the output. In the output layer the number of the neurons is equal to the number of the output (result) values, our amount of precipitation.

The sign arriving from the input neuron gets on each neuron of the next level after a multiplication with a weight $\left(w_{j}\right)$. The signs arriving on the neuron are summed up, then according to the transfer function, they appear on the output of the neuron. From here they get on to the neurons of the next layer multiplied with weight typical of the connection. This goes on until the output layer is reached. In the more complicated models - just like in reality - connections can be formed not only with the neurons of the next layer, but also with the ones in any layer, even a feedback is possible, so the sign appearing on the output can get back to the previous layer too.

For the use of ANN the weights $\left(w_{j}\right)$ must be determined, this is the teaching process. During learning the weights are determined based on known, connected data (results of measurement), in a way that the difference between the values got on the output of ANN and the known, measured data would be smaller than the given mistake.

Fig. 4. was made with the help of ANN, which demonstrates the yearly and seasonal changes well.

Kriging method [5, 22, 23]

The point of the method is that the result is calculated from the weighted average of the known data in a way that the deviation of the results would be minimal. The method examines how fast the deviation of the spatial points changes. This can be determined with the help of the so called variogram (semi-variogram) function which gives half of the square aggregate of the value differences gear to the distance between the points:

$$
\gamma(h)=\frac{1}{2 n(h)} \sum_{i=1}^{n(h)}\left(Z_{P_{i}}-Z_{P_{i+h}}\right)^{2},
$$

where $P_{i}$ 's are the measurement points, from where the known $\left(Z_{P_{i+h}}\right)$ values can still be found within $h$ distance. The $Z\left(P_{0}\right)$ value of the point $P_{0}$ to be calculated is estimated by the weighted average of the $Z\left(P_{i}\right)$ value of $n$ numbers of $P_{i}$ points. That is,

$$
Z\left(P_{0}\right) \approx \sum_{i=1}^{n} s_{i} Z\left(P_{i}\right)
$$

where $\sum_{i=1}^{n} s_{i}=1$. This is the case when the deviation of the estimation is minimal.

$S_{i}$ 's can be determined by the $S_{0}=K^{-1} C_{0}$ matrix equation, where the elements of $K$ (the Krige matrix) and $C_{0}$ can be calculated from the variogram.

\section{Inverse distance Weighting method [5, 22]}

The essence of the method is that the unknown data, based on the neighboring (known) data are determined in a way that the farther a point $\left(P_{i}\right)$ is the less effect is has on the result. It is taken into consideration with weight 
where:

$$
Z_{e}=\frac{\sum_{i=1}^{n} \frac{1}{d_{i}^{w}} Z_{i}}{\sum_{i=1}^{n} \frac{1}{d_{i}^{w}}}
$$

$Z_{e} \quad$ the searched value,

$d_{i} \quad$ the distance from the known $i$ point,

$Z_{i} \quad$ the value of the known $i$ point,

$w$ weight.

In the case of a surface we have:

$$
Y_{e}=\frac{\sum_{i=1}^{n} \frac{1}{\left|X_{e}-X_{i}\right|^{w}} Y_{i}}{\sum_{i=1}^{n} \frac{1}{\left|X_{e}-X_{i}\right|^{w}}} .
$$

As a result of weighing the effect of distant point is irrelevant, that is why in practice the effect of data is not taken into consideration beyond a certain distance (range).

Spline method [5, 10, 17]

If the scalar fieled is smooth enough then the so called "flexible thin membrane" model can be used for interpolation, where the surface can be approximated with polynomials of degree 3 .

The $P(u)$ curve is determined by the parameters $\left(P_{i}\right)$ of the known $n+1$ point.

$$
P(u)=\sum_{i=0}^{n} P_{i} N_{i, k}(u)
$$

where $N_{i, k}(u)$ is the weight function, the parameter $k$ is the degree number which gives the smoothness of the curve.

In case of surface modeling a surface is made as the Descartes product of two curves:

$$
P(u, v)=\sum_{i=0}^{n} \sum_{j=0}^{m} P_{i, j} N_{i, k}(u) N_{j, l}(v)
$$

Fig. 5 shows the results of the different interpolation methods.

\section{Moving average method}

Another way of creating a surface which is smooth enough for the representation of the digital surface model is the moving average method. According to [9], the model in $2 \mathrm{D}$ is given by:

$$
M A_{i}=\frac{1}{2 N+1} \sum_{j=-N}^{N} X_{i+j}
$$

where $N$ is the number of neighbors taken into consideration at the calculation of average.

As we dealt with 3D data spatial moving average had to be used:

$$
M A_{i, j}=\frac{1}{(2 N+1)^{2}} \sum_{k=-N}^{N} \sum_{l=-N}^{N} X_{i+l, j+k} .
$$


The results made by the consideration of different numbers of neighbors are shown in Fig. 6.

\section{Results}

Based on the precipitation data measured in Szeged Fig. 3 was made with the ordinary methods. It contains the changes in yearly precipitation, and the seasonal changes between 1931 and 1940. It can be seen in the figure that there is a tendency of slow decrease in the whole amount of precipitation and the seasonal changes can be observed too.
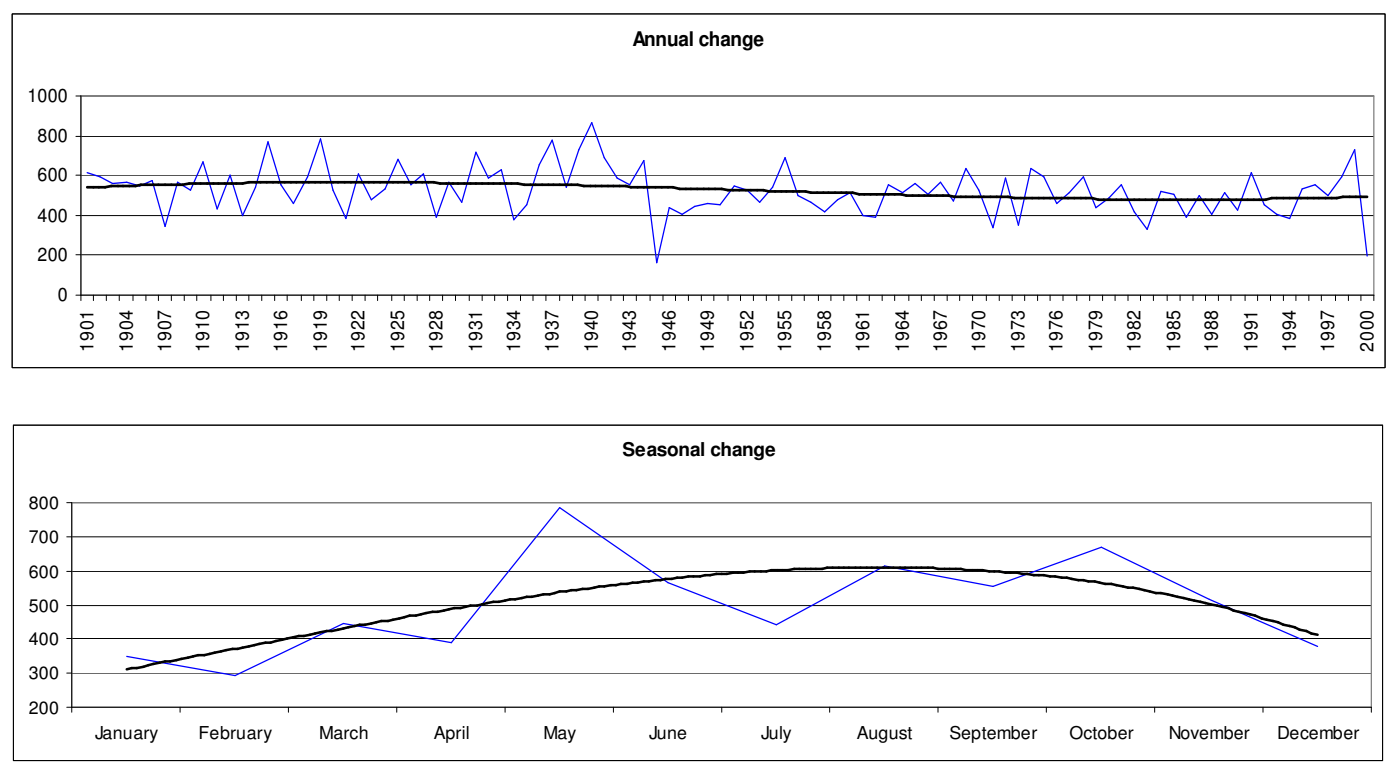

Figure 3. Precipitation yearly and monthly changes measured in Szeged

But the figure does not provide enough information about the changes, as no conclusion can be drawn about the seasonal changes from the yearly tendencies; and no information can be gotten about the yearly tendencies from the seasonal changes.

But the 3D presentation gives the opportunity for the joint presentation of the yearly and monthly (seasonal) data (Fig. 1). It can be seen in the figure that precipitation consists of random, independent data. That is why it is necessary to place a smooth enough surface on the set of points which shows the changes in a well interpretable form.

We have tried several methods to prepare the 3D surface/digital surface in order to be able to compare data: ANN (Fig. 4), kriging, inverse distance weighting, spline (Fig. 5 ). It was necessary to decrease the number of data for the interpolation and reaching the smooth enough surface which was achieved by the use of monthly and 5 and 10 years averages. Kriging's method turned out to be unusable several times becouse of smoothness problems. 


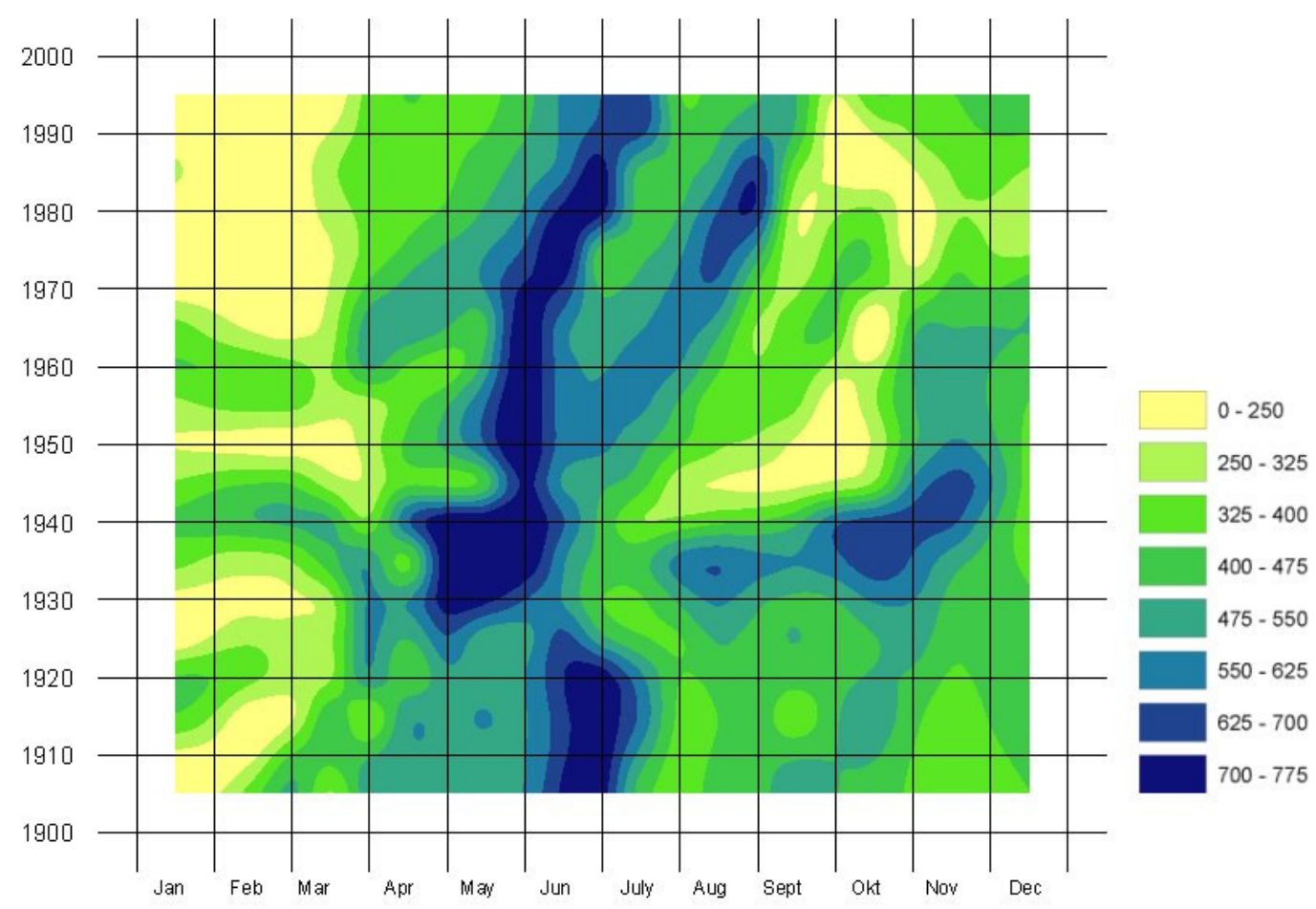

Figure 4. Monthly precipitation changes in Szeged with NN

\section{What remains is to draw a few easy conclusions from the coming figures}

In this article we have presented a 3D display method which allows on expensive and brief way of drawing conclusion. Visualization makes the recognition of tendencies on easy task.

Fig. 4 which was made with ANN, shows both the seasonal change (axis $x$ ) and yearly tendency (axis $y$ ) at the same time, unlike the traditional graphical representation (Fig. 1). The figure shows well that the most amount of precipitation at the beginning of the last century was, at the end of June. Then, from 1930, it is shifted to May and to the beginning of June. From 1960 it is continuously being shifted towards July. Winter (January, February) change is conspicuous where the amount of precipitation continuously decreases.

It is also conspicuous that the most precipitation was between 1930 and 1940, and that around 1950 the beginning of fall and winter was dry. Furthermore, the amount of precipitation decreases towards the end of the century. This tendency can also be seen in the "traditional" Fig. 3.

Fig. 5 has been made with a different interpolation method. It can be seen that the illustrated distribution of precipitation is similar to the one in Fig. 4. in case of the traditional interpolation methods the known (existing) data affects the final result much more; so these values in the figure appear as a well separable, discrete spots. Fig. 4, made by ANN, is more balanced (smoother), so the drawing made this way shows the tendencies of the changes more expressively. 


\section{Kriging:}

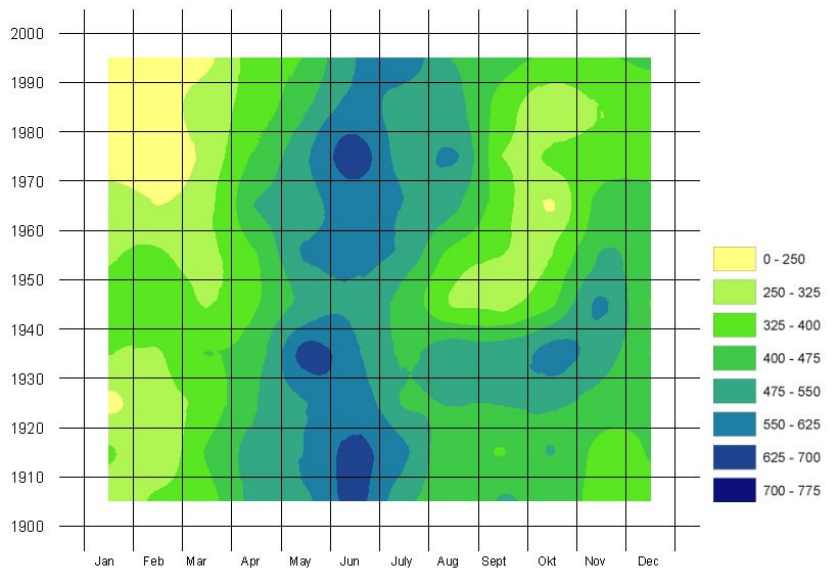

\section{Inverse Distance Weighting:}

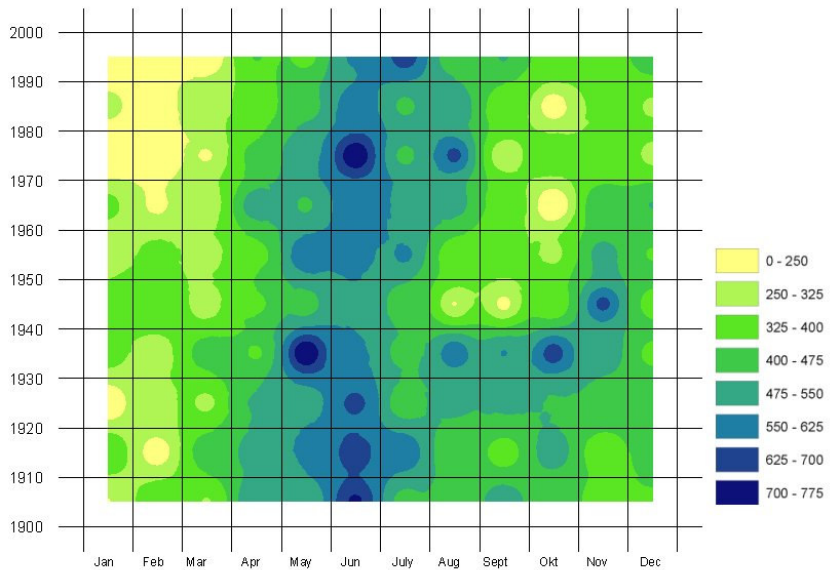

Spline:

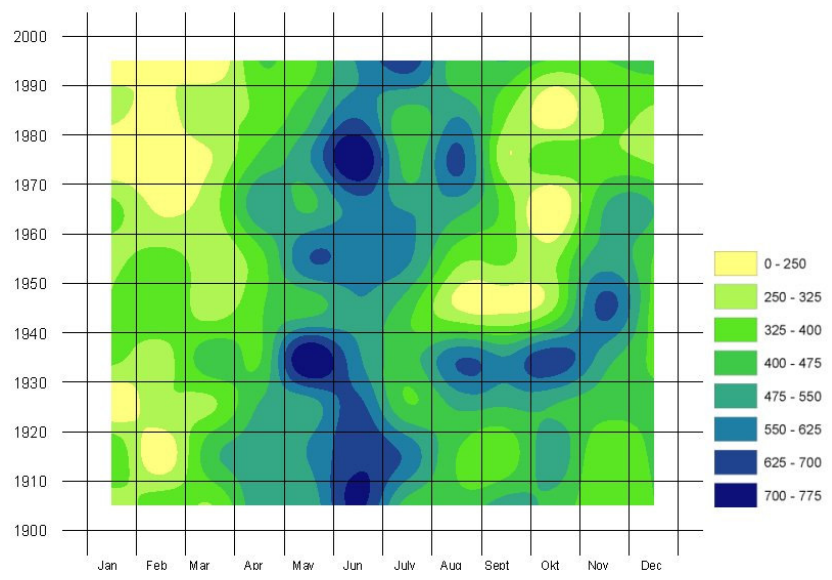

Figure 5. Monthly precipitation changes with interpolation methods

Fig. 6 has been made with the method of moving average, where we examined how the distance (number of neighbors) used with the model, affects the plot. In case of 5 neighbors, the surface is not smooth enough, but certain tendencies (e.g. seasonal 
changes) can still be recognized. In case of 10 neighbors the similarity to the former interpolation methods can be recognized in the figure; for example January and February is getting drier and drier with the increase of the years. This tendency can be seen in the figure with 20 neighbors, too.

\section{5 neighbors}

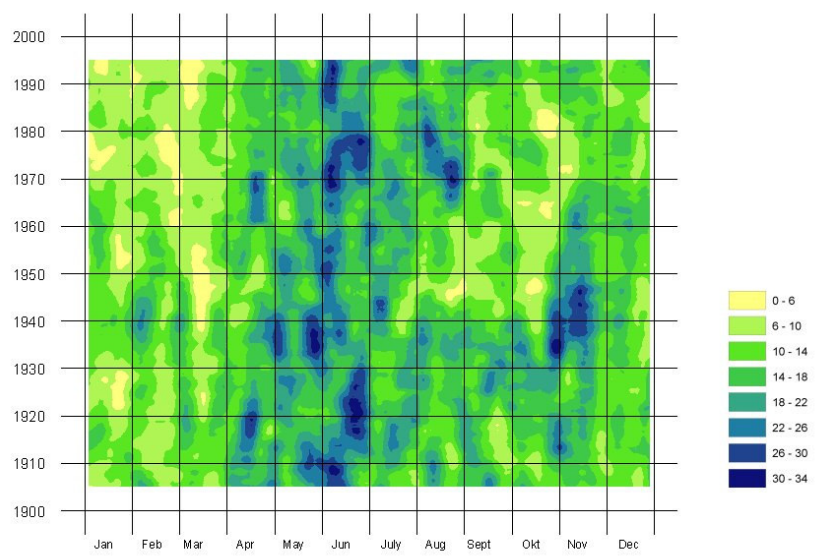

10 neighbors

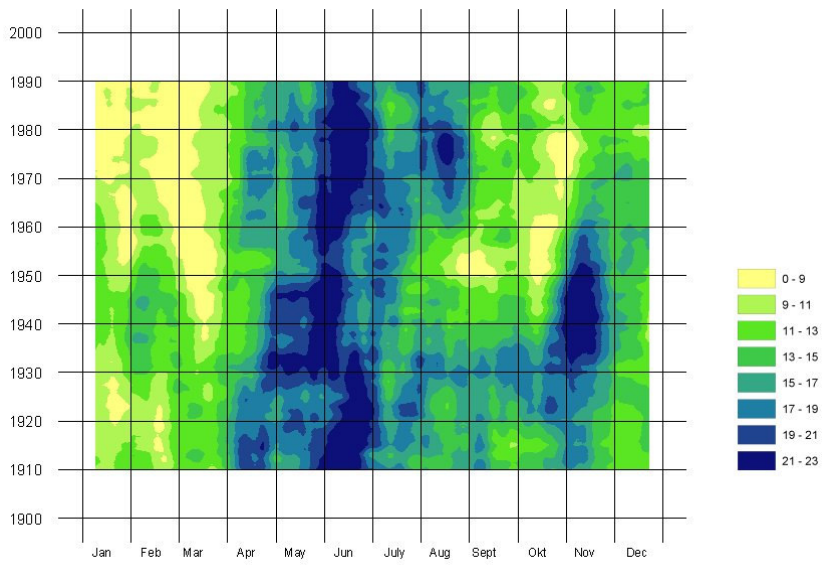

\section{0 neighbors}

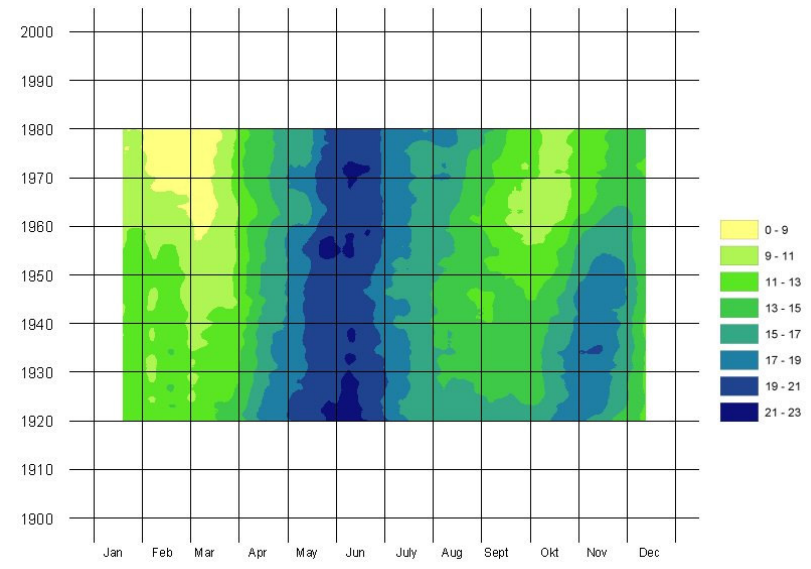

Figure 6. Monthly precipitation changes with moving average methods 


\section{Summary}

The daily amount of precipitation measured at the meteorological station of Szeged has been analyzed in the course of our job. The measurement data is represented with a digital surface model for the sake of better demonstration; in connection with this we reviewed a graphical display method, which we made the demonstration of the tendencies of precipitation changes more expressive compared to the quoted literature with.

The method review in this article was used successfully for the analysis of other climate data - e.g. temperature, evaporation - as well [25].

According to the case study above, the method is suitable to represent other, meteorological, ecological or environmental pollution time series. We suggest its use where the aim is to monitor the seasonal and yearly tendencies.

Acknowledgements. I express my acknowledgement to Prof. A. Anda and Prof. L. Szeidl for the support and constructive criticism in writing this article.

\section{REFERENCES}

[1] Antonić, O., Križan, J., Marki A., Bukovec D. (2001): Spatio-temporal interpolation of climatic variables over large region of complex terrain using neural networks Ecological Modelling 138: 255-263.

[2] Dibike, Y.B., Coulibaly, P. (2006): Temporal neural networks for downscaling climate variability and extremes - Neural Networks 19: 135-144.

[3] Dobi, I., Mika, J., Szeidl, L. (2000): Modelling wet and dry spells with mixture distribution - Meteorology and Atmospheric Phisics 73: 245-156.

[4] Gimesi L. (2004): Neurális hálózatok és térinformatikai alkalmazásuk, Térinformatika 7: 13-15.

[5] Gimesi, L. (2006): Examination of ion concentration of ground water - Acta Agraria Kaposváriensis 10: 53-63.

[6] Gong, D.Y., Shi P.J., Wang J.A. (2004): Daily precipitation changes in the semi-arid region over northern China - Journal of Arid Environments 59, 771-784.

[7] Heino, R, (1999): Homogeneity of the long-term urgan data record - Atmospheric environment 33: 3879-3883.

[8] Holmberg, M., Forsius, M., Starr, M., Huttunen, M. (2006): An application of artificial neural networks to carbon, nitrogen and phosphorus concentrations in three boreal streams and impacts of climate change - Ecological Modelling 195 51-60.

[9] Hoppe H., Kiely G. (1999): Precipitation Over Ireland - Observed Change Since 1940. Phys. Chem. Earth 24: 91-96.

[10] Iványi, A. (2004): Informatikai algoritmusok I. ELTE Eötvös kiadó, Budapest.

[11] Kocsis, T., Anda, A. (2006): A csapadék alakulása a keszthelyi hosszú idősoros meteorológiai megfigyelések alapján. J. of Central Eur. Agric. 4: 699-708.

[12] Kocsis, T., Anda, A. (2005): Az évi csapadékmennyiség változásának tendenciái Keszthelyen, 130 év mérése alapján. Légkör 50. 2: 16-21.

[13] Korn, G.A., Korn,T. M. (1975): Mathematical Handbook for Scientists and Engineers. McGraw-Hill Book Company (Hungarian ed.).

[14] Láng, I., Csete, L., Harnos, Zs. (1983): A magyar mezőgazdaság agroökológiai potenciálja az ezredfordulón - Mezőgazdasági kiadó, Budapest.

[15] Matějíček, L., Engst, P., Jaňour, Z. (2006): A GIS-based approach to spatio-temporal analysis of environmental pollution in urban areas: A case study of Prague's environment extended by LIDAR data - Ecological Modelling 199: 261-277. 
[16] Mulligan, M. (1998): Modelling the geomorphological impact of climatic variability and extreme events in a semi-arid environment - Geomorphology 24: 59-78.

[17] Newman, W.M., Sproull R.F. (1985): Principles of Interactive Computer Graphics McGraw-Hill Inc.

[18] Öztopal, A. (2006): Artifical neural network approach to spatial estimation of wind velocity data - Energy Conversion and Management 47: 395-406.

[19] Robinson, T.P., Metternicht, G. (2006): Testing the performance of spatial interpolation techniques for mapping soil properties - Computers and Electronics in Agriculture 50: 97-108.

[20] Sakata, S., Ashida, F., Zako, M. (2003): Structural optimization using Kriging approximation - Comput. Methods Appl. Mech. Engrg. 192: 923-939.

[21] Szeidl, L., Gimesi, L., Markó, T. (2005): Időjárás generátor és a sztochasztikus modellezés néhány kérdése. Plenáris előadás a VII. Magyar biometriai és biomatematikai konferencián. Budapest Corvinus University.

[22] Steiner, F. (1990): A geostatisztika alapjai. Tankönyvkiadó, Budapest.

[23] Teegavarapu, R.S.V., Chandramouli, V. (2005): Improved weighting methods, deterministic and stochastic data-driven model for estimation of missing precipitation record. Journal of Hydrology 312: 191-206.

[24] Tripathi, S., Srinivas, V.V., Nanjundiah, R. S. (2006): Downscaling of precipitation for climate change scenarios: A support vector machine approach. Journal of Hydrology 330: 621-640.

[25] Varga, B., Boldizsár, A., Gimesi, L. (2007): Some Remarks on Water Balance Components of Lake Balaton. Georgikon for Agriculture 10: 69-82. 